
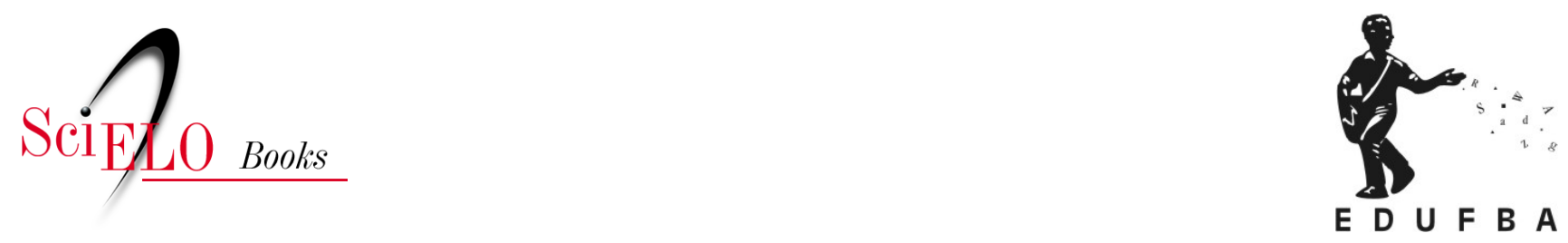

\title{
Pobreza e trabalho
}

\author{
José Carlos da Exaltação Torres
}

\section{SciELO Books / SciELO Livros / SciELO Libros}

TORRES, J.C.E. Pobreza e trabalho. In: Cadastro Único: tecnologia de reclassificação social [online]. Salvador: EDUFBA, 2016, pp. 43-61. ISBN: 978-65-5630-011-5. https://doi.org/10.7476/9786556300115.0005.

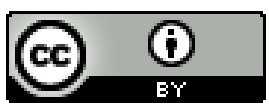

All the contents of this work, except where otherwise noted, is licensed under a Creative Commons Attribution 4.0 International license.

Todo o conteúdo deste trabalho, exceto quando houver ressalva, é publicado sob a licença Creative Commons Atribição 4.0. 


\section{POBREZA E TRABALHO}

Discutindo as lutas de classificação social, Bourdieu (2008, p. 445) antecipou que "os grupos estão associados estreitamente às palavras que os designam”, princípio a partir do qual se pode analisar o significado da palavra “pobreza”. Segundo o Dicionário Aurélio (2004), "pobreza”designa "a falta do necessário à vida; penúria, escassez" ou ainda "a classe dos pobres”, ao tempo em que "pobre" refere-se àquele "cujas posses são inferiores à sua posição ou condição social”. Recorrendo mais uma vez a Bourdieu (2004, p. 162), tem-se que a palavra "categoria", de origem grega, kathegoresthai, indica acusação: "acusar publicamente”. Em síntese, pobre é aquele que tem, no plano das designações e representações coletivas, a condição de "despossessão", enquanto que a categoria pobreza, "estado ou qualidade de pobre" (AURÉLIO, 2004), reúne num conjunto todos aqueles que se encontram nesta condição de carência. Mas, tomando como acertada a afirmação apresentada acima, de que "a reunião num mesmo lugar de uma população homogênea na despossessão tem também como efeito redobrar a despossessão" (BOURDIEU, 1997, p. 166), a designação de pessoas como o grupo dos pobres pode funcionar como um instrumento arriscado de reiteração de uma condição que só existe em relação à estrutura das condições que se diferenciam dela e que, simultaneamente, a fazem diferente; exprime um estado social de correlação de forças numa dada estrutura social.

Considerando a abordagem discutida anteriormente, admite-se que existem princípios de diferenciação definidores da localização dos agentes no espaço social, fato condicionado ao volume e à qualidade dos "capitais" que possuem (capital econômico, cultural, simbólico) ou mesmo que não 
possuem. Desta perspectiva, compreende-se que a pobreza, enquanto categoria social, é um fenômeno que tem, na base de sua significação, um processo de distinção social. Em verdade, esta é como que a forma paroxística de toda diferença, de toda separação, de toda segregação que as classificações sociais promovem, porque se as diferenças de condições sempre criaram distinções entre os humanos, decerto a relegação à condição de pobre é um fenômeno relativamente recente, decorrente das transformações ocorridas com a modernização das sociedades, notadamente pela implementação do modo de produção capitalista nas sociedades ocidentais. E é, sim, como toda distinção, o resultado de lutas sociais e das representações sociais dessas lutas, especialmente políticas, que criaram fronteiras sociais tão poderosas, e de tal modo evidenciadas, que se impõem como inevitáveis. Como observa Marshall (1967), referenciada num contexto onde o mérito é a riqueza, a pobreza figura como fracasso.

Assim, o ponto de partida para tratar do tema da pobreza está no reconhecimento de que este fenômeno não é algo dado, como a apreciação imediata das condições de vida diferenciais pode sugerir, mas que ele resulta de uma construção histórico-social, decorrente do embate de interesses conflitantes, empiricamente expressos nas relações entre o capital e o trabalho e nas formas de regulação do mercado de trabalho, majoritariamente realizadas pelo Estado. Confrontada com os mecanismos legítimos de produção e reprodução social, a pobreza figura como o aspecto mais negativo do conflito social. A sua emergência enquanto fenômeno de massa, no contexto das sociedades urbano-industriais, torna-a um divisor de águas na história da humanidade, marcada pela alteração efetiva do modo e das relações de produção na Europa Ocidental dos séculos XVIII e XIX. A posse ou não sobre os meios de produção tornou-se a propriedade diferencial por excelência, pois constituiu, em última instância, a posse sobre os meios de reprodução da própria vida, e a "falta do necessário à vida" subordinou os segmentos sociais despossuídos, quase que completamente e em todos os aspectos da vida, aos segmentos possuidores. Uma dependência que significou, a fundo, um risco à vida, precisamente um risco de morte, porque é o "outro" que detém a posse sobre as formas de subsistência. A pobreza é uma condição, portanto, de subordinação explícita e necessária de uma classe (objetiva) a outra (dos trabalhadores aos capitalistas); subordinação que se tornou a condição de existência dos trabalhadores. Em palavras simples, quem não 
vender a força de seus braços - e a energia de seu corpo - pode estar condenado a morrer de fome.

Essa situação de dependência, porém, é insuficiente para definir a condição de pobre, porque, por ela, chegar-se-á à fácil conclusão de que todo trabalhador é pobre e se, nestes termos, for considerada como acertada a afirmação de que "a história de toda sociedade até hoje é a história da luta de classes" onde "opressores e oprimidos sempre estiveram em constante oposição uns aos outros” (MARX; ENGELS, 1999, p. 66), não há nada que permita estabelecer a diferença ou o corte entre a modernidade e os períodos que a antecederam. Assim, como já demonstraram autores clássicos, como Marx e Engels, é no próprio modelo produtivo que se encontra a chave da questão. O sistema capitalista é essencialmente contraditório e excludente, porque, ao tempo em que estabelece como princípio de sobrevivência o trabalho assalariado e disponibiliza no mercado os recursos indispensáveis a essa sobrevivência, não gera oportunidades de assalariamento para todos aqueles colocados nesta situação e, consequentemente, nega o acesso a tais recursos. O mercado de trabalho, via de inclusão social para todos os que dispõem apenas de sua força de trabalho para sobreviver, sustenta-se em princípios geradores de exclusão. Desta forma, a pobreza é marcada principalmente por uma condição de incerteza em relação ao trabalho e consequentemente à sobrevivência, e mesmo pela imposição da condição de "falta do necessário à vida" a extensos contingentes populacionais.

\section{AMBÍGUA NOÇÃO DE LIBERDADE NAS NOVAS RELAÇÕES DE TRABALHO}

Foi essa condição de vida a que os trabalhadores foram empurrados que Engels (1985) constatou na Inglaterra do século XIX. Milhares de pessoas apinhadas em bairros de miséria ostensiva, tanto pela ausência dos víveres básicos quanto de infraestrutura sanitária ou qualquer tipo de saneamento. Habitações precárias e extremamente insalubres. Populações inteiras famintas, andrajosas. Uma tal situação que parece confirmar o paradoxo de uma parábola bíblica, na qual um patrão severo pune com a expropriação absoluta o empregado que não soube multiplicar os seus "talentos": "Tirem dele o talento, e deem ao que tem dez. Porque a todo aquele que tem, será dado mais, e terá em abundância. Mas daquele que não tem, até o que tem lhe será tirado". (BÍBLIA, 199o, Mt 25: 29) E o que tinha, afinal, o trabalha- 
dor em questão, se não a sua força de trabalho? Se não a própria vida que via esvair-se como a água que não obedece aos limites da mão?!

A leitura que Engels (1985) faz daquela situação, considerando as nuanças da condição de "trabalhador livre" dos operários, permite-lhe concluir que houve uma acentuação do grau de vulnerabilidade em relação à condição de escravos de outrora, dadas as incertezas da condição de assalariado.

A única diferença em relação à antiga escravatura, praticada abertamente, está em que o trabalhador atual parece ser livre, porque não é vendido definitivamente mas pouco a pouco, diariamente, semanalmente, anualmente e porque não é o proprietário que o vende a outro, mas é ele próprio que é obrigado a vender-se desta maneira; porque não é escravo de um só proprietário mas de toda a classe possuidora. (ENGELS, 1985, p. 97-98, grifo do autor)

É certamente nesta constatação de Engels que Marx (1980) se inspira ao analisar a relação entre trabalho assalariado e capital poucos anos após, pois a sua conclusão beira à transcrição, tamanha a semelhança:

O escravo é vendido, com a sua força de trabalho, duma vez para sempre, ao comprador. [...] É ele mesmo que constitui a mercadoria e não a sua força de trabalho.

[...] O operário livre, pelo contrário, vende-se a si mesmo, pedaço a pedaço. Vende em leilão oito, dez, doze, quinze horas de sua vida, dia após dia, a quem melhor pagar, aos proprietários das matérias-primas, dos instrumentos de trabalho e dos meios de vida, isto é, aos capitalistas. O operário não pertence a nenhum proprietário [mas como o seu] único recurso é a venda da sua força de trabalho, não pode desligar-se de toda a classe de compradores [...] sem renunciar a existência. (MARX, 1980, p. 19, grifo do autor)

Com o mercado de trabalho, criou-se a condição de assalariado, a qual impõe, por apanágio, condições precárias de vida aos trabalhadores, dadas pela exploração exacerbada de sua força de trabalho, transformada em mercadoria, a qual comporta dois aspectos fundamentais: é a força viva da produção, e por isso, a fonte de reprodução do capital; e a fonte de sua própria reprodução, porque o seu preço é o salário, condição de acesso aos meios de subsistência. Tendo que alugar-se para terem acesso aos víveres de que necessitam para manter-se, os trabalhadores fazem-se subordinados àqueles cuja posição permite que lhes recuse os préstimos e a outros, em semelhante situação, eleja para realizá-los. O trabalhador adentra forçosamente 
nessa "guerra social" já em plena desvantagem por não dispor daquilo que se constitui a arma fundamental e condição sine qua non de vitória: a propriedade sobre os meios de produção, pelo que se sujeita a viver na miséria, ladeado da opulência cuja força de seus braços é a essência. Se não por ironia do acaso, decerto por uma dialética perversa da sociedade capitalista, opulência e miséria parecem competir na exibição do que têm de mais sensível entre si; de mais sedutor numa e de mais horrendo noutra!

Engels (1985) trata a situação que analisa por “assassinato social”, porque os operários não têm meios para manter a saúde nem para viver longamente, e a sociedade faz-se insensível ante tal situação. É aterrorizante o grau de adoecimento entre os trabalhadores, notadamente nas situações em que surgem as epidemias. As condições de habitabilidade e de alimentação altamente precárias tornam essas pessoas extremamente vulneráveis a doenças das mais diversas etiologias, pelo que se faz patente a tendência à elevação da miserabilidade e à quase que inexorável mendicância.

[...] quando a sociedade [isto é, a classe que atualmente possui o poder político e social] põe centenas de proletários numa situação tal que ficam necessariamente expostos à morte prematura e anormal; [...] quando retira a milhares de seres os meios de existência indispensáveis, impondolhes outras condições de vida com as quais lhes é impossível subsistir; [...] quando sabe, quando está farta de saber, que estes milhares de seres serão vítimas destas condições de existência, e contudo as deixa persistir, então é de fato um assassinato, [...] um assassinato do qual ninguém se pode defender, porque não parece um assassinato porque o assassino não se vê. (ENGELS, 1985, p. 115)

A força de trabalho é uma mercadoria cuja mensuração pauta-se no tempo de sua utilização (MARX, 1980), e se a extensão da vida pode ser medida também através do tempo, o exercício da força de trabalho corresponde ao exercício da vida, assim, é a sua própria vida que os trabalhadores alugam, paradoxalmente, para se manter vivendo. O salário torna-se, portanto, um indicador das condições de vida, porque ele antecipa o nível de consumo dos meios de subsistência dispostos no mercado. No que tange à administração capitalista, Marx (1980) analisa que o salário compõe o custo de produção das mercadorias e, considerando que o lucro se mede em relação a esse custo, a redução dos salários aparece como uma tendência inevitável da produção capitalista. "Lucro e salário estão [...] na razão inversa um do outro". (MARX, 198o, p. 37) Por outro lado, sendo a força de trabalho também mer- 
cadoria, comporta também custo de produção, o que se mede pelo "custo necessário para conservar o operário como operário e para fazer dele um operário" (MARX, 1980, p. 25, grifo do autor), o que remete principalmente ao "preço dos meios de subsistência necessários" (MARX, 1980, p. 25, grifo do autor) para a sua manutenção e reprodução.

A pobreza não está, assim, na condição de trabalhador, mas no tipo de relação social que ela exprime. E, embora assumindo os riscos de arbitrariedade de um salto temporal e histórico, não é demasiado afirmar que as condições de vida a que está relegada grande parte das populações empobrecidas do mundo atual pouco ou nada ficam devendo às que se submeteram os trabalhadores europeus dos séculos XVIII e XIX. Isso não quer dizer que o que se tem hoje se constitui numa transposição de um modus vivendi europeu anacrônico, pautado numa experiência incipiente de capitalismo e numa sociedade também pouco experimentada em termos de democracia. Definitivamente, não é isso. Mas o que ali se criou e se replicou para o mundo não foi apenas um modelo produtivo, mas todo um sistema social forjado nas desigualdades entre os indivíduos, afinal, o capitalismo tem como princípio de desenvolvimento a competição, e como indicador principal da competição, o grau de desigualdade expresso nas relações sociais. Sendo de caráter totalizante, articula-se com todas as esferas da vida social e em todos os aspectos de cada esfera. E essa noção é indispensável para qualquer análise que se tente realizar sobre o fenômeno da pobreza. É como a analogia que Castel (1998) faz entre os "supranumerários" de ontem e de hoje, numa referência à população que não se enquadra em nenhuma categoria de classificação social, pela ausência de possibilidades de inserção estável "nas formas dominantes de organização do trabalho" (CASTEL, 1998, p. 28), por não ter "nenhum lugar determinado na estrutura social nem em seu sistema de distribuição de posições”. Uma analogia permitida, segundo o autor, "não por uma identidade de condição, [...] mas por uma homologia de posição”. (CASTEL, 1998, p. 96)

O saldo negativo das formas ou oportunidades de inserção social em relação ao contingente populacional necessitado dessa inserção (o que, em termos atuais, pode ser dito pelo diminuto número de postos de trabalho 
em relação ao contingente de desempregados?) já se enunciava desde o século XIV, como se observa nas análises de Castel (1998). Naquele momento, essa situação estava associada a outros fatores, como a emergência da categoria de trabalhadores livres cuja condição contrapunha-se às formas de regulação tradicional do trabalho, situação semelhante, aliás, à que se verificará no Brasil séculos mais tarde. É relevante, neste sentido, a natureza das regulamentações formais que intentam evitar a mobilidade territorial dos trabalhadores, e mesmo a modificação de seu estatuto social, sugerindo uma tentativa de conservação da ordem social tradicional. Exemplo categórico disso é a citação que o autor faz de um decreto denominado "Estatuto dos Trabalhadores”, do Rei da Inglaterra, de 1349, do qual se expõe aqui um fragmento:

Que cada súdito, homem ou mulher, [...] livre ou servil [bord], que seja válido, com menos de sessenta anos de idade, que não viva do comércio [...] ou que não exerça ofício de artesão [craft], que não possua bens dos quais possa viver, nem terras a cuja cultura possa dedicar-se e que não esteja a serviço de ninguém [...], se for requisitado a servir de um modo que corresponda a seu estado, será obrigado a servir àquele que assim o tiver requisitado; e receberá, pelo lugar que será obrigado a ocupar, somente o pagamento em gêneros, alimento ou salário que estava em uso durante o vigésimo ano de nosso reinado, ou durante os cinco ou seis anos precedentes. (CASTEL, 1998, p. 97, grifo do autor)

Castel (1998, p. 102) identifica aí, e no conjunto das regulamentações emitidas à época por toda a Europa, os princípios de um código de trabalho, elaborado por "poderes centralizados e poderes municipais [que] conspiram em sua vontade de enclausurar o trabalho em suas configurações tradicionais" e que, portanto, previnem contra alterações nas formas vigentes de organização do trabalho, mas, também, contra a dilatação dos critérios de acesso à assistência, ${ }^{8}$ impedindo que a população fisicamente capaz de trabalhar engrossasse as fileiras dos assistidos. O surgimento dos trabalhadores livres, ainda na Idade Média, inaugura, então, a saga da desfiliação a

7 De modo algum pretende-se aqui reduzir a problemática colocada a uma situação simplificada de oferta e demanda, como essa relação dual pode sugerir; a forma como está expressa é antes um recurso linguístico que analítico.

8 Analisando a origem e desenvolvimento da assistência social, Castel (1998) identifica a existência de dois critérios seletivos fundamentais: a) o pertencimento comunitário e b) a inaptidão ou incapacidade para o trabalho. 
que diversas populações estarão sujeitas com a emergência e consolidação do sistema social capitalista, e da qual a figura do "vagabundo" se oferece como expoente, porque associa a essa condição decorrente de transformações histórico-sociais, através de deliberações políticas (que também estão em sua causa), um estigma excludente, transformando um estado social em um atributo individual. $\mathrm{O}$ autor observa que o indivíduo tratado por vagabundo é um homem "sem trabalho nem bens [e] é também um homem que não tem um senhor, nem onde cair morto. 'Morando em toda parte' [...] é um ser de lugar nenhum”. 9 (CASTEL, 1998, p. 120)

Colocado como um problema social, o "vagabundo" é alvo de toda sorte de condenações que atravessaram séculos: o banimento das comunidades em que se encontrava, a deportação para as colônias, a reclusão, a realização de trabalho forçado, a pena de morte. ${ }^{10}$ Castel (1998) ressalta que não pretende inocentar os "vagabundos" e admite a existência de situações em que práticas não isoladas de indivíduos correspondiam à classificação atribuída, mas observa que essa categoria é uma construção social que generaliza as características de um grupo específico sobre uma extensa população, a qual experimenta uma diversidade de situações de privação e desfiliação, de miséria e instabilidade, de vulnerabilidade, enfim, e, em sua maioria, involuntariamente. $O$ autor considera que "essa construção de um paradigma negativo do vagabundo é um discurso do poder" (CASTEL, 1998, p. 136), um instrumento de gestão dessa população. "A política repressiva com respeito à vagabundagem representa a solução para uma situação que não comporta solução" (CASTEL, 1998, p. 136); a designação e a representação genérica e negativa do vagabundo, portanto, homogenízam a heterogeneidade de situações que não têm lugar na estrutura social, alocando-as, em conjunto, numa posição que, ao invés de questionar a ordem social, torna passível a condenação, porque representa uma escolha daqueles. E aqui se torna bastante adequada a abordagem de Bourdieu (2008), que considera as

$9 \quad$ Há um curta metragem de Jorge Furtado - produzido no Rio Grande do Sul, em 1989, cujo nome, Ilha das Flores, reproduz o nome do lugar que lhe dá enredo - que traduz de forma bastante dura e real a condição a que chegou a população pobre daquele lugar, que disputa entre si os restos de um lixão, após ter sido garimpado e retirados os "melhores" restos para alimentar porcos. Um trecho do texto final é emblemático: "O que coloca os seres humanos da llha das Flores depois dos porcos na prioridade de escolha de alimentos, é o fato de não terem dinheiro nem dono". Vale à pena conferir!

Ver em: Castel (1998, p. 122-128). 
formas de classificação e representações como instrumentos de poder e de dominação. A “desfiliação" nada mais é que a própria desclassificação elevada à máxima potência, que permite a imposição de uma localização social, desprovida de todo prestígio, a quem supostamente não tem nenhuma.

É nessa figura do vagabundo que Castel (1998) vai buscar o germe da condição de assalariamento moderna, porque representava o indivíduo que nada possuía, senão a força de seus braços. Paradoxalmente, não estavam postas as condições para "alugá-la", pois as regulamentações do trabalho tanto organizavam as formas de produção quanto estabeleciam barreiras à criação de um mercado de trabalho livre. "A participação em um ofício [...] marca o pertencimento a uma comunidade distribuidora de prerrogativas e de privilégios que asseguram um estatuto social para o trabalho". (CASTEL, 1998, p. 155) O vagabundo não sustentava vínculos com qualquer comunidade, como determinavam as prescrições legais, tampouco se adequava à realização de um ofício, inclusive pelas barreiras impostas por essas mesmas prescrições, a exemplo do "Estatuto dos Artesãos”, que exigia um período extenso de aprendizagem para a realização do ofício, proibia a migração entre campo e cidade - para que os artesãos do campo não oferecessem concorrência aos urbanos - proibia a aprendizagem no meio rural - para não subordinar excessiva mão de obra a um senhor - e, por fim, tornou-se um ofício hereditário, reservado aos filhos de artesãos. (CASTEL, 1998, p. 177) Assim, os trabalhadores livres tinham em sua liberdade os seus grilhões, porque toda relação de trabalho dava-se dentro da regulação do Estado, e este não admitia a existência de um novo perfil de trabalhador. É por isso que Castel (1998, p. 198) considera que “o estado de assalariado [que prevalecerá na modernidade] não nasceu da liberdade ou do contrato, mas da tutela".

Castel (1998) assimila as formas de trabalho assalariado presentes nas sociedades pré-industriais ao serviço de corveia, no que tange ao tipo de relação estabelecida, de submissão a um senhor, o que reduz a diferença, estrita e justamente, ao pagamento de uma remuneração, de um salário que não necessariamente deveria ser pago em moeda, situação que corresponde notadamente à condição dos assalariados rurais durante o processo de "desconversão" da sociedade feudal: por um lado são livres, mas, por outro, “[prisioneiros] do sistema tradicional de coerção". (CASTEL, 1998, p. 201) A condição de assalariado "remete a uma extrema diversidade de situações, mas que caracterizam quase exclusivamente atividades sociais impostas 
pela necessidade e enquadradas por relações de dependência”. (CASTEL, 1998, p. 205)

Tentar reconstituir o que podia ser a condição de assalariado nesse tipo de sociedade é, pois, referir-se a um conjunto de situações que têm em comum uma certa indignidade. Ser assalariado não conota somente a miséria material, situações de pobreza ou próximas da pobreza mas, também, estados de dependência que implicam uma espécie de subcidadania ou de infracidadania em função dos critérios que, para a época, asseguram um lugar reconhecido no conjunto social. (CASTEL, 1998, p. 204)

A condição do vagabundo na sociedade pré-industrial desenhava já, portanto, o destino para toda uma classe de agentes cuja filiação social corresponde mais a um estigma que a uma identidade ou estatuto. Naquelas sociedades, não havia alternativa aos desfiliados, senão o trabalho assalariado, fato que por si só dava conotação negativa à condição assalariada. Essa era a condição destinada à população "aleatória", sem lugar ou posição definida na estrutura social, aliás, é justamente nisso que consiste a questão social a que Castel (1998) dedica a sua análise: o lugar ocupado por essas pessoas na ordem social, e é diante disso que o autor inquire "em que vai se transformar a situação desses grupos" na era moderna. Se havia, pois, uma questão social posta pelo desajuste entre um novo perfil de trabalhadores e as formas tradicionais de organização do trabalho, essa questão será reformulada no século XIX - paradoxalmente numa ordem onde o trabalho livre corresponde ao princípio legítimo de integração social - em função desses mesmos trabalhadores.

Analisando aproximações estatísticas sobre os indigentes na Europa Ocidental entre os séculos XIV e XVII, Castel (1998) conclui que existe aí uma "indigência estrutural" que engloba algo em torno de $5 \%$ da população. Mas o autor ressalta também o caráter “conjuntural” da indigência, no sentido de que as condições de precariedade em que viviam as populações menos favorecidas empurravam-lhes fatalmente para a indigência diante de qualquer perturbação na conjuntura. A partir do século XVII, pois, acontece uma tomada de consciência em relação ao fenômeno, que deixa de ser concebido como uma questão residual para compreender a condição a que estava sujeita a maioria do povo. “O caráter inaceitável da miséria e os riscos de dissociação social nela contidos deixam então de atingir essencialmente [...] os assistidos e os desfiliados. Tornam-se um risco que afeta a condição 
laboriosa enquanto tal, isto é, a maioria do povo da cidade e do campo". (CASTEL, 1998, p. 220)

Além dessa consciência sobre a vulnerabilidade de massa, Castel (1998) afirma que houve uma modificação também na concepção sobre o trabalho, considerado, até então, uma obrigação daqueles que dependiam exclusivamente da própria força para sobreviver e representava, por isso mesmo, a ausência de riquezas. "O trabalho é [...] o quinhão dos pobres e dos que ganham pouco, reduzidos à necessidade de trabalhar a matéria ou de cultivar a terra para sobreviver" (CASTEL, 1998, p. 227), está inscrito numa concepção que alia necessidade e coerção. Do século XVIII para o XIX, porém, faz-se imperativo o trabalho livre, porque corresponde a uma sociedade de mercado, o qual se pretende "não regulado", seja nas relações de produção ou na comercialização de seus produtos. A noção de liberdade que fundamenta a nova concepção do trabalho é, a fundo, um princípio de ordenação social de cunho liberal. A liberdade, então, representava uma oposição a todas as antigas formas despóticas de submissão do trabalho forçado e de controle das velhas oligarquias sobre os servos. Representava, por conseguinte, a independência de um mercado de trabalho em relação ao poder do Estado. A este cabe apenas "garantir que o jogo dos interesses possa expressar-se livremente” (CASTEL, 1998, p. 233), eliminando as barreiras para a consecução dos lucros.

Castel (1998) utiliza-se das formulações de Turgot (além de Adam Smith e outros), como ideólogo do liberalismo, para demonstrar a força com que a modernidade se lançou contra as formas tradicionais do trabalho (o trabalho forçado e o trabalho regulado), evocando, inclusive, a noção de um direito natural ao trabalho, demonstrando um verdadeiro translado da concepção, que passa da obrigação ao direito.

\begin{abstract}
A liberdade do trabalho tem a legitimidade de uma lei natural, ao passo que as formas históricas de sua organização são contingentes. Disso resulta que, como até o presente foram colocadas sob o registro da coerção, essas formas são arbitrárias e despóticas. [...] É urgente abolir essa herança do mundo velho para deixar as leis naturais intervirem. (CASTEL, 1998, p. 235)
\end{abstract}

Liberdade, então, ao trabalho, liberdade ao mercado, liberdade à acumulação de riquezas das quais, agora, o trabalho representava o fundamento. Liberdade em relação à tutela, à regulação estatal que se impunha, as- 
sim, como óbice ao progresso. O elemento principal dessa mudança parece estar na supressão da regulação sobre as relações de produção, no fato de dar liberdade para que as duas classes de agentes principais do sistema que se impunha pudessem decidir livremente sobre a adequação de seus interesses. "O recurso ao contrato [...] significa que são os sujeitos sociais que se auto-instituem como coletivo ao invés de serem dominados por uma Vontade exterior que os comanda de cima”. (CASTEL, 1998, p. 240-241) A mera abertura de um mercado de trabalho pressupunha, portanto, a possibilidade objetiva de todos trabalharem, num jogo de complementaridade entre diferentes interesses, o que revela, de saída, uma "ambiguidade fundamental”, por duas questões especificamente: primeiro, há um "desequilíbrio estrutural” entre o número de trabalhadores e as oportunidades objetivamente existentes e, segundo, o jogo de interesses estabelecia um antagonismo entre as classes, elementos que darão o caráter da nova questão social. (CASTEL, 1998)

Essa perspectiva restaura, em contrapartida, a possibilidade de reprimir, e agora legitimamente, aqueles que voluntariamente não se adéquam à nova ordem: os vagabundos e os mendigos válidos. "Enquanto os 'antigos governos' se desonravam condenando inocentes privados de trabalho, o novo fará obra de justiça punindo com sanções os parasitas que fogem à dura lei do trabalho quando lhes é aberta a possibilidade de trabalhar". (CASTEL, 1998, p. 248) Nesse bojo, a concepção de assistência é também reformulada, no sentido de se garantir auxílio aos "verdadeiros" inválidos, e um auxílio que agora se constituía numa obrigação do Estado. Nesse arranjo de complementaridade entre o econômico e o político da França revolucionária de fins do século XVIII, o trabalho cabe, portanto, ao liberalismo, e a assistência ao Estado, o que, aliás, Castel (1998) considera uma contradição, e que findará no insucesso do arranjo, porque a estrutura organizada para os “socorros públicos" exigia a constituição de um Estado forte, inverso ao que propõe a ideologia liberal. "A articulação, à primeira vista harmoniosa, do direito aos socorros e do livre acesso ao trabalho dissimula, dessa maneira, o antagonismo entre dois princípios de governabilidade: o do Estado social e o do Estado liberal”. (CASTEL, 1998, p. 257)

Além disso, há uma ambiguidade também inscrita na concepção de livre acesso ao trabalho, fazendo com que, mais uma vez, esse "direito" se converta em "obrigação". De um lado porque o Estado, em decorrência dessa liberação, não é obrigado a garantir oportunidades de trabalho e, por ou- 
tro, pelo fato das sanções à indigência válida e à vagabundagem obrigarem todo "cidadão" a trabalhar. Para Castel (1998, p. 259), "“impor a necessidade do trabalho' é ainda referir-se ao trabalho forçado exatamente no momento em que se proclama a liberdade do trabalho". A ambiguidade está posta, portanto, na "própria noção de direito" que pesava sobre os trabalhadores e os submetia, a fundo, aos interesses dos empregadores que tinham a liberdade de definir a remuneração do trabalho.

A ideia de negociação findava nula ante o imperativo da necessidade e da lei, e fazia da classe empregadora a reguladora mesmo das relações de produção e do trabalho enfim. A liberdade não regulada apresenta, então, os seus limites, e por si só converte-se numa prisão inextricável em que o trabalhador se vê colocado; há uma "guerra social" onde a pura liberdade expõe abertamente os trabalhadores no campo inimigo. A "indignidade" da condição salarial não é superada, portanto, com a liberalização do trabalho.

\section{CIDADANIA VERSUS MERCADO: RELAÇÕES ESTABELECIDAS NA PERSPECTIVA DOS DIREITOS}

Essa concepção de liberdade nas relações de trabalho torna-se mais ambígua quando tomada da perspectiva dos direitos, como o faz Thomas Marshall (1967) ao discutir a noção de cidadania, porque permite tratar a questão sob a ótica da desigualdade social, considerando também aspectos culturais e políticos, além dos econômicos. Para esse autor, a cidadania refere-se à construção de um sistema de direitos constituído em três dimensões, que são complementares entre si, mas não necessariamente indispensáveis para a existência individual de cada uma, enquanto direito civil, político e social, e que dão conta, respectivamente, dos direitos concernentes às liberdades individuais - podendo-se vislumbrar a liberdade do trabalho discutida acima; a participação direta ou indireta nas instâncias políticas e o direito a um padrão de vida equivalente ao padrão comum da sociedade. A existência da cidadania sugere uma sociedade pautada em regulações formais, onde a posição social dos agentes é dada em razão de um estatuto comum, e não pelo status ou origem (ou "honraria”, para usar uma expressão weberiana) (WEBER, 1982), como supõe uma sociedade estamental. E é em referência a um "código uniforme de direitos" (MARSHALL, 1967, p. 64) que se pode mensurar os graus de desigualdade impingidos a determinados grupos sociais em relação a outros. 
Segundo Marshall (1967), no contexto histórico mundial, os direitos de cidadania desenvolveram-se de forma apartada, podendo ser localizados, para efeitos analíticos, em séculos distintos: direitos civis no século XVIII, direitos políticos no século XIX e direitos sociais no século XX. Do ponto de vista econômico, o direito civil se pauta no direito de trabalhar e numa ocupação de livre escolha. A sua adoção na Europa significou a revogação dos atos que impunham o trabalho servil, determinavam as profissões e restringiam o território de trabalho. $\mathrm{O}$ autor considera que, ao anunciar-se o século XIX, o status de liberdade era já uma condição consolidada. Obviamente, as condições de vida enfrentadas pelas classes operárias naquele século, como demonstrado nas análises de Engels (1985) anteriormente discutidas, revelam os estreitos limites dessa liberdade e a distância posta entre o trabalho concebido como direito e a sua efetivação real. Se havia direitos de cidadania consolidados, longe ainda estava a possibilidade de os trabalhadores assumirem a sua condição de cidadãos.

Quanto aos direitos políticos, segundo Marshall (1967, p. 69), se não foram criados a partir do século XIX, foram ampliados "a novos setores da população", pois o autor considera que a sua deficiência não estava no conteúdo, mas nas formas de distribuição. A partir da década de 1830, transitou-se de um "monopólio fechado" a um "monopólio aberto" do direito ao voto; monopólio porque ainda restrito a determinados grupos, notadamente os habilitados economicamente, mas ainda assim ampliados, considerando os padrões da época. Ainda segundo o autor, os direitos políticos eram secundarizados em relação aos civis, o que pode indicar a precedência da economia em relação à política, fato que teria sido superado durante o século XX, quando o status pessoal, e não o econômico, teria passado a ser a base dos direitos políticos.

Os direitos sociais são referenciados à antiga Poor Law inglesa, a qual Marshall (1967, p. 71) afirma ser remanescente de um "amplo programa de planejamento econômico", que se desarticulou por ser contradito à emersão da economia competitiva. Neste sentido, a cidadania guardaria uma contradição em sua base, pois enquanto os direitos civis vinculam-se à nova ordem social, os direitos sociais teriam uma referência na ordem antiga. Essa interpretação fundamenta-se nas análises de Karl Polanyi (2000) sobre a Speenhamland Law, um sistema de abonos criado na Inglaterra aos fins do século XVIII (1795), que garantia uma renda mínima à população pobre, instituindo-lhe o "direito de viver", o que teria significado uma forma de 
resistência da ordem social tradicional à criação de uma ordem competitiva, com o estabelecimento de novas formas de regulação das relações de trabalho.

Merece destaque, porém, a observação de Polanyi, de que a Speenhamland se fez um elemento crucial para a compreensão da história social da civilização ocidental a partir do século XIX, pois nela está em destaque a figura do indigente, fator que despertara no homem ocidental a sua consciência de coletividade, da existência da sociedade humana - o que, mais tarde, aliás, terá reflexos sobre a interpretação do fenômeno da pobreza, do ponto de vista moral, e não socioeconômico, desvinculando-o da questão da desigualdade. Para esse autor, “[...] o estudo da Speenhamland é o estudo do nascimento da civilização do século XIX”. (POLANYI, 200o, p. 106) O espírito social imanente à vivência humana despertara com o movimento causado pela Speenhamland. De fato, se a pergunta que incomodava as mentes pensantes daquele momento era "de onde vêm os pobres?", o contexto analisado não tem nada a dever aos problemas sociais vigentes ainda hoje, muito pelo contrário, aliás. Neste sentido, pode-se afirmar que Marshall se equivoca, pois não parece correto entender os direitos sociais como algo típico de uma ordem social retrógrada. Em verdade, a criação de um sistema de abonos complementar ao salário antecipa a necessidade de criação de sistemas de proteção social, demandados na sociedade capitalista efetiva, como forma de compensar as desvantagens impostas pelos mecanismos de competição dessa ordem.

Contudo, Marshall (1967) admite que a Speenhamland Law constituiu um "elemento de previdência social", de garantia de renda de acordo com as necessidades e o "status de cidadão", fadada ao fracasso, porém, por contrariar os princípios predominantes. Isso a fizera passar de uma "defensora agressiva dos direitos sociais da cidadania” (MARSHALL, 1967, p. 72) para uma alternativa a tais direitos, concedida, assim, a quem deixasse "inteiramente de ser cidadão".

O estigma associado à assistência aos pobres exprimia os sentimentos profundos de um povo que entendia que aqueles que aceitavam assistência deviam cruzar a estrada que separava a comunidade de cidadãos da companhia de indigentes. (MARSHALL, 1967, p. 72) 
Para o autor, é através da educação, tida como "um direito social de cidadania genuíno” (MARSHALL, 1967, p. 73), que se fará a conciliação entre as diferentes dimensões da cidadania.

Para Thomas Marshall (1967, p. 76), "cidadania é um status concedido àqueles que são membros integrais de uma comunidade”, conferindo-lhes iguais direitos e obrigações, em referência a um fim ideal de igualdade de condições. No capitalismo, as desigualdades são utilizadas como estímulo ao esforço pessoal e determinam as frações de "distribuição de poder", e, sendo importantes ao funcionamento do sistema, não têm limites definidos. Esse sistema desigual deu origem à pobreza e à indigência, e sendo a riqueza o referente ideal ou o bônus do mérito pessoal, a pobreza se converte em fracasso. O despertar da consciência social a esse respeito leva à perseguição de mecanismos para a redução das desigualdades, mas os benefícios concedidos pela assistência não incidem sobre as bases do sistema de classes. Como afirma o autor, “[...] os benefícios recebidos pelos infelizes não se originaram de um enriquecimento do status da cidadania”. (MARSHALL, 1967, p. 79)

A cidadania, desde o início do seu desenvolvimento, alimentava o princípio da igualdade. O seu ajuste à desigual sociedade capitalista foi possível porque os direitos que postulava eram direitos civis, aqueles relacionados às liberdades individuais e que, a fundo, corroboravam as desigualdades, indispensáveis que eram estas à competição mercadológica. O status de cidadania serviu, assim, como base à edificação do sistema de desigualdades, não por deficiência nos direitos civis, mas por ausência dos direitos sociais.

[Os direitos civis] Davam a cada homem, como parte de seu status individual, o poder de participar, como uma unidade independente, na concorrência econômica, e tornaram possível negar-lhes a proteção social com base na suposição de que o homem estava capacitado a proteger a si mesmo. (MARSHALL, 1967, p. 79, grifo do autor)

Tendo isso em conta, é no modelo Welfare State de proteção social que se verificará a possibilidade de conciliação entre capitalismo e cidadania, pois que cria os mecanismos para a operação, de forma universalizada, dos direitos sociais.

A noção de "Welfare" tem referência originalmente no contexto pósguerra, no hemisfério Norte, mas, após as formulações de Esping-Andersen (1991), concebendo a existência de diferentes "regimes” de Welfare Sta- 
te, o conceito deslocou-se para as iniciativas de Estados nacionais em favor da compatibilização das atividades econômicas e das condições de vida da população, no intuito de promover o bem-estar social. Esping-Andersen (1991, p. 101) afirma que a "ideia fundamental de um welfare state" é composta pela noção de cidadania social, mas observa que, no cumprimento desta cidadania, os direitos sociais devem ser equivalentes aos direitos de propriedade e "assegurados com base na cidadania", e não no desempenho, elemento característico da competição, considerando, ainda, que a cidadania confere status equivalente ao de classe, constituindo, portanto, um fator de estratificação social.

Ao tratar da constituição do Welfare State no mundo, Esping-Andersen (1991) afirma que todo o debate sobre o tema envolve duas questões básicas; primeiro refere-se ao grau de transformação que esse tipo de política pode realizar na sociedade capitalista e, segundo, tange à causalidade do desenvolvimento desse modelo. Essas são questões que, afirma o autor, datam de um século antes da existência do que se convencionou tratar por Welfare State e se situam na relação entre capitalismo e bem-estar social, redundando na relação entre Estado e mercado, ou mesmo entre propriedade e democracia. Neste sentido, a sua análise considera três tipos de economias políticas segundo as quais se formularam as noções de Welfare State: liberal, conservadora e marxista.

Sob a perspectiva liberal, os mercados capitalistas são dotados de uma capacidade de autoajuste e de promoção da igualdade entre os indivíduos, e por isso a intervenção do Estado é desnecessária, e mesmo prejudicial, porque representa a defesa dos interesses de grupos privilegiados em detrimento de outros e promove desequilíbrio no livre jogo concorrencial. Assim, já no liberalismo clássico, considerava-se que “[...] o caminho para a igualdade e a prosperidade deveria ser pavimentado com o máximo de mercados livres e o mínimo de interferência estatal" (ESPING-ANDERSEN, 1991, p. 86), e é uma posição homóloga a esta que atualmente assume o neoliberalismo. A vertente conservadora, por outro lado, defende a hierarquização social com centralização política como única forma de manutenção da ordem; a sua posição é de afrontamento ao liberalismo e representa uma visão oposta no que diz respeito à superação dos conflitos de classe oriundos do capitalismo. Esse tipo de economia política, segundo Esping-Andersen (1991, p. 87), representou uma reação à Revolução Francesa e à Comuna de Paris, pois, a fundo, "temia a nivelação social”, considerando que "status, 
posição social e classe eram naturais e dadas; mas os conflitos de classe, não”. A perspectiva marxista, por sua vez, envolve elementos dessas duas vertentes, posicionando-se contra ambas, pois considera que o Estado é gerador de privilégios e defensor de interesses particulares, mas também que a acumulação de propriedade, propiciada pela ordem liberal, contradiz a noção de igualdade e é promotora de divisões sociais.

A despeito dos princípios que diferenciam essas vertentes, segundo Esping-Andersen (1991), a noção de democracia apresentava-se para todas como problemática. Para os liberais, ameaçava a eficiência do mercado; para os conservadores, diluiria as divisões sociais, e com elas a própria ordem social; e para os marxistas, enfim, não passava de uma falácia sem efetividade para a luta dos trabalhadores. Obviamente, essa postura foi revista pelos socialistas, mas, segundo o autor, só após conquistas reais de direitos políticos, quando se constatou que, embora tenham sido implementadas para controlar a mobilização dos trabalhadores, as reformas sociais representaram conquistas, porque "[...] o equilíbrio do poder de classe altera-se fundamentalmente quando os trabalhadores desfrutam de direitos sociais". (ESPING-ANDERSEN, 1991, p. 89)

Para Esping-Andersen (1991), há que se reconceituar a noção de Welfare State, considerando o entrelaçamento entre Estado, família e mercado, e mesmo a relação entre direito e "desmercadorização" da força de trabalho, o que consiste em criar condições para a emancipação das pessoas frente ao mercado, no sentido de reduzir o seu grau de dependência das relações monetárias para sobreviver. A desmercadorização "ocorre quando a prestação de um serviço é vista como uma questão de direito" (ESPING-ANDERSEN, 1991, p. 102), ou seja, o direito emancipa os indivíduos, dá-lhes autonomia e segurança ante as desigualdades do mercado, o que, por outro lado, lhes dá condições para a sua mobilização. Neste sentido, partindo de uma perspectiva comparativo-histórica, o autor formula um agrupamento analítico de três distintos modelos de regime de Welfare State ocorridos no mundo: liberal, tradicional (ou corporativista) e social-democrata.

No primeiro modelo, liberal, que tem nos Estados Unidos, Canadá e Austrália seus principais exemplos, há predominância do mercado com "assistência aos comprovadamente pobres, reduzidas transferências universais ou planos modestos de previdência social”. (ESPING-ANDERSEN, 1991, p. 108) Há, portanto, reduzida desmercadorização, com estigmatização dos beneficiários e promoção da estratificação, baseada no tipo de relação esta- 
belecida pelos indivíduos, se com o Estado ou com o mercado. No segundo, tradicional (conservador corporativista) - Áustria, França, Alemanha e Itália -, o critério do status é que define o acesso aos direitos, e o Estado desempenha o papel principal, embora no sentido de fortalecer ou preservar a família tradicional, suprindo as suas deficiências; uma decorrência da relação desse modelo com a Igreja. O terceiro modelo, o social-democrata, constitui-se numa "fusão peculiar de liberalismo e socialismo" (ESPING -ANDERSEN, 1991, p. 110), adotando-se para as reformas sociais os princípios do universalismo e da desmercadorização. A qualidade dos serviços prestados equivale ao grau da demanda existente. Ou seja, a satisfação que oferece garante-lhe a legitimação necessária à sua manutenção. Benefícios graduados permitem a inclusão de todas as camadas sociais num amplo sistema previdenciário, redundando num apoio generalizado ao Welfare State .

O principal aspecto a se destacar dessa formulação é que as vias de acesso aos direitos sociais têm implicação direta na posição ocupada pelos agentes na estrutura social, bem como na legitimação dessa posição, e, neste sentido, o papel desempenhado pelo Estado pode ser preponderante na definição dessas vias, algo que, por sua vez, está condicionado a que esfera da cidadania tem precedência na organização social em jogo (civil, política ou social). Em sociedades como a brasileira, essa equação se torna um pouco mais complexa, porque a mudança social se faz com a reiteração de componentes históricos destoantes da ordem que os sucede, como se verá na discussão a seguir. 